Postgraduate Bosowa University Publishing (PBUP)
Indonesian Journal of Business and Management
e-ISSN: $2460-3767 \quad p$-ISSN: $2656-6885$
INttps://postgraduate.universitasbosowan
JOURAL

\title{
ANALISIS KESESUAIAN PEKERJAAN INDIVIDU, MODAL MANUSIA TERHADAP KINERJA PEGAWAI KONTRAK DAN KEPUASAN KERJA SEBAGAI VARIABEL INTERVENING PADA BADAN KEPEGAWAIAN DAN PENGEMBANGAN SUMBER DAYA MANUSIA DAERAH DI KOTA MAKASSAR
}

\author{
Analysis of Individual Job Suitability, Human Capital on Contract Employee Performance and Job \\ Satisfaction as Intervening Variables at the Regional Personnel and Human Resources Development \\ Agency in Makassar City
}

\author{
Evi Indah Sari ${ }^{1}$, Oesman Lewangka ${ }^{2}$, Miah Said ${ }^{2}$ \\ ${ }^{1}$ BPKSDMMD. Kota Makassar \\ ${ }^{2}$ Program Studi Manajemen Program Pascasarjana Universitas Bosowa \\ Email: indahsarievi29@gmail.com
}

Diterima: 20 September 2021/Disetujui: 24 Desember 2021

\begin{abstract}
ABSTRAK
Tujuan dari penelitian ini adalah untuk mengetahui dan menganalisis pengaruh kesesuaian pekerjaan individu, modal manusia terhadap kepuasan kerja dan kinerja pegawai kontrak, pengaruh kepuasan kerja terhadap kinerja pegawai kontrak, pengaruh kesesuaian pekerjaan individu dan modal manusia terhadap kinerja pegawai kontrak melalui kepuasan kerja. Teknik pengumpulan data melalui observasi, interview dan dokumentasi serta kuesioner. Sedangkan teknik analisis data yang digunakan adalah analisis PLS. Hasil penelitian menemukan bahwa kesesuaian pekerjaan individu berpengaruh terhadap kepuasan kerja, modal manusia memberikan pengaruh secara nyata dalam meningkatkan kepuasan kerja, Pengaruh kesesuaian pekerjaan individu memberikan pengaruh secara nyata terhadap peningkatan kinerja pegawai kontrak. Pengaruh modal manusia akan memberikan dampak dalam meningkatkan kinerja pegawai kontrak. Kepuasan kerja memberikan pengaruh secara nyata terhadap peningkatan kinerja pegawai kontrak. Hasil uji mediasi menunjukkan bahwa kepuasan kerja tidak dapat memediasi pengaruh kesesuaian pekerjaan individu terhadap kinerja pegawai kontrak. Hasil uji mediasi menunjukkan bahwa kepuasan kerja dapat memediasi pengaruh modal manusia terhadap kinerja pegawai kontrak. Hal ini dapat diindikasikan bahwa semakin tinggi modal manusia akan meningkatkan kepuasan kerja sehingga berdampak terhadap kinerja pegawai kontrak, oleh karena itu maka disarankan agar sering melaksanakan diklat, melakukan promosi jabatan serta menempatkan pegawai sesuai dengan bidang skill yang dimiliki oleh pegawai.
\end{abstract}

Kata Kunci: Person Job Fit, Modal Manusia, Kepuasan Kerja dan Kinerja Pegawai Kontrak

\begin{abstract}
The purpose of this study was to determine and analyze the effect of individual job suitability, human capital on job satisfaction and contract employee performance, the effect of job satisfaction on contract employee performance, the effect of individual job suitability and human capital on contract employee performance through job satisfaction. Data collection techniques are through observation, interviews and documentation as well as questionnaires. While the data analysis technique used is PLS analysis. The results of the study found that individual job suitability had an effect on job satisfaction, human capital had a significant effect on increasing job satisfaction, and individual job suitability had a significant effect on improving contract employee performance. The influence of human capital will have an impact in improving the performance of contract employees. Job satisfaction has a significant effect on improving the performance of contract employees. The results of the mediation test indicate that job satisfaction cannot mediate the effect of individual job suitability on the performance of contract employees. The results of the mediation test show that job satisfaction can mediate the effect of human capital on the performance of contract employees. This can be indicated that the higher human
\end{abstract}


Hubungan Gaya Kepemimpinan Tranformasional dan..... (Muhammad Subhan Kadir, Thamrin Abduh, Firman Menne)

capital will increase job satisfaction so that it has an impact on the performance of contract employees, therefore it is recommended that they often carry out training, carry out promotions and place employees according to the skill areas possessed by employees.

Keywords: Individual Job Suitability, Human Capital, Job Satisfaction, Performance of Contract Employees

(c) (i)

This work is licensed under Creative Commons Attribution License 4.0 CC-BY International license

\section{PENDAHULUAN}

Dewasa ini era globalisasi mengharuskan setiap individu untuk tangguh dalam menghadapi tantangan dan persaingan dalam pekerjaan. Sumber daya manusia sebagai penggerak roda suatu organisasi dituntut untuk dapat menguasai setiap pekerjaan dengan maksimal dan menghasilkan kinerja kerja yang tinggi. Oleh karena itu dibutuhkan strategi manajerial dan sumber daya manusia yang handal. Sumber daya manusia merupakan salah satu aspek yang paling penting dan asset organisasi yang paling mahal, sehingga harus dikelola dengan baik, agar tujuan organisasi dapat tercapai melalui pencapaian kinerja pegawai.

Widodo (2016) mengatakan bahwa kinerja merupakan hasil kerja seseorang yang dihasilkan dari beberapa kegiatan dalam proses pelaksanaan tugas pekerjaan yang dibebankan kepada pegawai dan telah ditentukan standar yang sesuai dengan wewenang dan tanggung jawab untuk mencapai tujuan organisasi yang telah ditentukan. Untuk meningkatkan kinerja pegawai maka banyak faktor yang perlu diperhatikan oleh organisasi salah satunya adalah kepuasan kerja, sebagaimana dikemukakan oleh Priansa (2018) bahwa kepuasan kerja merupakan sekumpulan perasaan pegawai terhadap pekerjaannya, apakah senang atau tidak senang sebagai hasil interaksi pegawai dengan lingkungan pekerjaannya atau sebagai persepsi sikap mental, juga sebagai hasil penilaian pegawai terhadap pekerjaannya. Perasaan pegawai terhadap pekerjaannya mencermi-nkan sikap dan perilakunya dalam bekerja. Ini menunjukkan bahwa pegawai yang memiliki kinerja yang tinggi biasanya memiliki kepuasan kerja yang tinggi pula.

Banyak faktor yang mempengaruhi kinerja dan kepuasan kerja, dimana dalam penelitian ini difokuskan pada variabel kesesuaian pekerjaan individu dan modal manusia. Kesesuaian pekerjaan individu berpengaruh terhadap kinerja pegawai sebagaimana dikemukakan oleh Bowen, et.al. (1997) menyatakan bahwa kesesuaian pekerjaan individu (person job fit) memperhitungkan jenis-jenis individu yang diperlukan dengan kualifikasi: kesesuaian knowledge (pengetahuan), skill (keterampilan), abilities (kemampuan), social skills (keterampilan sosial), personal needs (kebutuhan individu), values (nilai-nilai), interest (minat) dan personality traits (sikap individu). Dengan demikian penting bagi organisasi untuk melakukan penyesuaian pekerjaan individu, sehingga memperoleh kinerja individu yang optimal. Penelitian Jeanita (2017) menunjukkan bahwa kesesuaian pekerjaan individu atau person job fit berpengaruh signifikan terhadap kinerja karyawan.

Kemudian kesesuaian pekerjaan individu berpengaruh terhadap kepuasan kerja, dinana Hect dan Allen, dalam Peng dan Mao (2014) menyatakan bahwa kesesuaian pekerjaan individu (person job-fit) dikatakan dapat meningkatkan efikasi diri yang kemudian dapat memberikan kepuasan kerja ketika pegawai berhasil mencapai performa yang lebih baik dalam pekerjaannya. Sedangkan pegawai dengan kesesuaian yang rendah akan lebih sulit menyelesaikan tugas pekerjaannya, sehingga mengakibat-kan akan lebih sering dikritik oleh atasan dan cenderung mengalami pengalamanpengalaman negatif dalam melakukan pekerjaannya sehingga karyawan akan memiliki efikasi diri yang rendah. Penelitian Widyastuti, Titis dan Ratnaningsih (2018) hasil penelitian menunjukkan adanya hubungan positif yang signifikan antara kesesuaian pekerjaan individu (person job-fit) dengan kepuasan kerja. Semakin tinggi maka akan semakin tinggi kepuasan kerja.

Selain kesesuaian pekerjaan individu, maka modal manusia berpengaruh terhadap kinerja pegawai dan kepuasan kerja, dimana menurut Mayo (2000) mengatakan bahwa sumber daya manusia atau modal manusia mempunyai lima komponen. Setiap komponen dari modal manusia tersebut memiliki peranan yang berbeda-beda dalam menciptakan modal manusia di dalam organisasi yang pada akhirnya akan menentukan nilai dari suatu organisasi tersebut. Sumber daya manusia yang digunakan untuk mendukung keberhasilan kinerja organisasi bukanlah sumber daya manusia berkompetensi rendah. Bahkan sebaliknya, sumber daya manusia yang dibutuhkan dalam kinerja organisasi haruslah sumber daya manusia multi dimensi dan memiliki semangat kerja yang tinggi demi mencapai suatu target kinerja tertentu.

Kemudian modal manusia berpengaruh terhadap kepuasan kerja, sebagaimana yang dilakukan oleh Affandi (2016) hasil analisis yang diperoleh memberikan indikasi bahwa semakin baik modal manusia maka semakin baik pula kepuasan kerja yang dirasakan pegawainya. Kepuasan kerja sebagai variabel intervening antara person job fit sebagaimana dilakukan oleh Fidyannissa, Author (2013) menemukan bahwa kepuasan kerja tidak dapat menjadi variabel mediator pada pengaruh person job fit terhadap kinerja pegawai. Sedangkan pengaruh variabel mediator antara modal manusia terhadap kinerja pegawai melalui kepuasan kerja, sebagaimana penelitian Paradiptha (2013) menemukan adanya hubungan yang kuat antara modal manusia dan kepuasan kerja terhadap kinerja pegawai, bahwa pegawai dengan kemampuan/skill dalam pekerjaan dengan tingkat kepuasan kerja yang tinggi akan mempunyai kinerja yang tinggi pula terhadap organisasi.

Pentingnya kesesuaian pekerjaan individu (person job fit) dan modal manusia, maka penelitian ini dilakukan pada Badan Kepegawaian dan Pengembangan Sumber Daya Manusia Daerah, sebagai instansi pemerintah yang merupakan salah satu perangkat daerah yang memiliki tugas pokok melaksanakan sebagian urusan peme-rintahan di 
lingkup manajemen kepegawaian. Dimana dalam melaksanakan tugas pokok, BKPSDMD kota Makassar mempunyai fungsi melaksanakan perumusan kebijakan teknis, pembinaan dan pelaksanaan lingkup perencanaan, kesejahteraan pegawai, pengembangan karier pegawai, mutasi pegawai serta pendidikan dan pelatihan, melaksanakan tugas lain yang diberikan Walikota sesuai tugas dan fungsinya, serta melakukan pembinaan, monitoring, evaluasi dan laporan kegiatan Badan. Sehingga dengan luasnya ruang lingkup Badan Kepegawaian dan Pengembangan Sumber Daya Manusia Daerah maka dituntut kinerja yang tinggi dari masing-masing pegawai.

Berdasarkan hasil survey yang dilakukan pada Badan Kepegawaian dan Pengembangan Sumber Daya Manusia Daerah (BKPSDMD) maka diperoleh beberapa permasalahan yang terjadi selama ini, dimana pertumbuhan rata-rata kinerja pegawai mengalami penurunan. Adanya penurunan kinerja pegawai selama tahun 2019 karena adanya ketidaksesuaian pekerjaan dengan bidang ilmu yang dimiliki oleh setiap pegawai sehingga mengakibatkan masih adanya ketidakpuasan pegawai dengan penempatan kerja yang telah ditentukan oleh kantor Badan Kepegawaian dan Pengembangan Sumber Daya Manusia Daerah (BKPSDMD) selama ini.

\section{METODE}

\section{a. Jenis Penelitian}

Jenis penelitian yang digunakan dalam penelitian ini adalah dengan pendekatan kuantitatif yang menitikberatkan pada pengujian hipotesis, data yang digunakan harus terukur, dan membuat prediksi serta mendapatkan makna dan aplikasi dari suatu masalah menjadi suatu hubungan kausalitas yang ingin dipecahkan, sehingga dapat ditarik kesimpulan atau digeneralisasikan. Jenis penelitian ini dimulai dengan teori-teori dan hipotesis, langkah selanjutnya adalah membuat model analisis, mengidentifikasi variabel, membuat definisi operasional, mengumpulkan data populasi dan sampel serta melakukan analisis. Penelitian ini menggunakan teknik analisis PLS (Partial Least Square).

\section{b. Populasi dan Sampel}

Menurut Sugiyono (2017), Populasi merupakan wilayah generalisasi yang terdiri atas objek atau subjek yang mempunyai kualitas dan karakteristik tertentu yang ditetapkan oleh peneliti untuk dipelajari dan kemudian ditarik kesimpulannya. Populasi pada penelitian ini adalah pegawai kontrak pada BKPSDMD yang berstatus sebagai karyawan kontrak yang berjumlah 50 orang. Sedangkan sampel adalah bagian dari jumlah dan karakteristik yang dimiliki oleh populasi tersebut. Sedangkan untuk menentukan sampel maka peneliti menggunakan metode sampling jenuh, apabila jumlah populasi sedikit atau kurang dari 100 orang maka jumlah populasi dapat dijadikan sebagai jumlah keseluruhan sampel dalam penelitian ini. Sehingga jumlah sampel ditentukan sebanyak 50 orang pegawai kontrak.

\section{c. Variabel Penelitian}

Variabel-variabel yang digunakan dalam penelitian ini terdiri atas variabel bebas, variabel terikat, dan variabel mediasi. Berikut adalah penjelasan tiap variabel :

1) Variabel Bebas (X)

Variabel bebas atau Independent variabel merupakan variabel yang berfungsi untuk mempengaruhi variabel lain, menurut Sugiyono (2017) bahwa "Variabel Independen merupakan variabel yang mempengaruhi atau yang menjadi sebab perubahan atau timbulnya variabel dependen". Variabel bebas dalam penelitian ini adalah kesesuaian pekerjaan individu dan modal manusia.

2) Variabel Terikat (Y)

Variabel terikat juga dapat disebut sebagai variabel output. Menurut Sugiyono (2017) variabel dependen merupakan variabel yang dipengaruhi atau yang menjadi akibat, karena adanya variabel Bebas. Variabel terikat dalam penelitian ini adalah kinerja pegawai.

3) Variabel intervening $(\mathrm{Z})$

Variabel intervening adalah variabel yang secara teoritis mempengaruhi hubungan antara variabel independen dengan dependen, tetapi tidak dapat diamati dan diukur, melainkan membantu mengkonsepkan dan menjelaskan pengaruh variabel bebas terhadap variabel terikat. Variabel ini merupakan variabel penyela atau antara di dalam hubungan variabel bebas (X) dan variabel (Y), Sehingga variabel bebas (X) tidak langsung mempengaruhi variabel terikat (Y) (Sugiyono, 2017). Dalam penelitian ini yang bertindak sebagai variabel antara atau variabel intervening adalah kepuasan kerja.

\section{d. Jenis dan Sumber Data}

Data kuantitatif adalah data yang berbentuk bilangan atau angka-angka, Sugiyono (2017) menyatakan bahwa data kuantitatif merupakan data kuantitatif merupakan data yang berbentuk angka-angka atau data kualitatif yang diangkakan, dalam penelitian ini adalah data hasil pengukuran yang dapat dinyatakan dalam bentuk angkaangka, yang meliputi skor nilai dari jawaban kuesioner yang telah diisi oleh responden.

Sumber data yang digunakan dalam penelitian ini adalah:

1) Data primer merupakan sumber data penelitian yang diperoleh secara langsung dari sumber asli tanpa melalui perantara. Terdapat dua metode yaitu survey dan observasi. Data primer pada penelitian ini berupa data hasil pengisian kuesioner yang disebarkan pada Badan Kepegawaian dan Pengembangan Sumber Daya Manusia Daerah.

2) Data sekunder dalam penelitian ini adalah data yang diperoleh dengan cara membaca, mempelajari, dan memahami melalui media lain yang bersumber dari literatur, buku-buku, serta dokumen perusahaan berkaitan dengan informasi mengenai kesesuaian pekerjaan individu dan modal manusia terhadap 
kinerja pegawai kontrak dan kepuasan kerja sebagai variabel intervening.

\section{e. Teknik Pengumpulan Data}

Teknik pengumpulan data yang digunakan dalam penelitian ini dengan menggunakan cara sebagai berikut :

1) Observasi

Pengamatan dilakukan secara langsung oleh peneliti dengan datang dan berbaur di tempat penelitian, untuk mencocokkan kesesuaian antara hasil data dan keadaan di lapangan.

2) Survey dan wawancara

Survey dan wawancara dilakukan untuk memperoleh informasi tambahan yang dapat menunjang penelitian yang dilakukan. Dengan adanya wawancara yang dilakukan maka akan mendapatkan informasi yang dibutuhkan terkait dengan data penunjang dalam penelitian ini.

\section{f. Teknis Analisis Data}

Analisis data dalam penelitian ini dengan menggunakan metode analisis sebagai berikut :

1) Analisis Partial Least Square (PLS).

Analisis Partial Least Square (PLS) dapat digunakan pada setiap jenis skala data (nominal, ordinal, interval, rasio) serta syarat asumsi yang lebih fleksibel. Jogiyanto (2016) menambahkan bahwa PLS bertujuan untuk memprediksi pengaruh variabel $\mathrm{X}$ terhadap $\mathrm{Y}$ dan menjelaskan hubungan teoritikan diantara kedua variabel.

2) Uji Validitas dan Realibilitas Konstruk

Menurut Jogiyanto (2016) bahwa uji validitas konstruk menunjukkan seberapa baik hasil yang diperoleh dari penggunaan suatu pengukuran sesuai teori-teori yang digunakan untuk mendefinisikan suatu konstruk (variabel dalam kuesioner). Untuk melihat hubungan antar variabel digunakan teknik analisis PLS (Partial Least Square), Ghozali (2018). Teknik ini dapat digunakan pada data yang kecil, minimal 30 data. Kemudian teknik PLS ini selain digunakan untuk mengkonfirmasikan teori, juga digunakan untuk menjelaskan ada tidaknya hubungan antar variabel.

3) Measurement (Outer) Model atau Uji Model Pengukuran

Outer model dibagi menjadi dua yaitu reflektif dan formatif. Outer model digunakan untuk mengetahui validitas dan reliabilitas yang menghubungkan indikator dengan variabel latennya. Definisi operasional variabel dapat dijadikan dasar, dalam penelitian ini perancangan model pengukuran yang didapatkan dari sifat indikator masing-masing variabel laten yang bersifat reflektif.

4) Structural (Inner) Model atau Uji Model Struktural Tujuan dari uji model struktural adalah melihat korelasi antara konstruk-konstruk yang diukur yang merupakan uji t dari partial least square itu sendiri. Structural model dapat diukur dengan menggunakan beberapa kriteria, yaitu :

a) $R^{2}$ untuk variabel laten endogen atau dependen. b) Estimasi koefisien jalur. Hal ini merupakan nilai estimasi untuk hubungan jalur dalam model struktural yang diperoleh dengan prosedur bootstrapping dengan nilai yang dianggap signifikan jika nilai $\mathrm{t}$ statistik lebih dari 1,96 untuk masingmasing hubungan jalur yang ada.

a) Relevansi prediksi (Q2). Apabila diperoleh nilai Q2 lebih dari nol, hal tersebut memberikan bukti bahwa model memiliki predictive namun apabila diperoleh nilai Q2 dibawah nol, maka terbukti bahwa model tidak memiliki predictive relevance.

5) Evaluasi Goodness of Fit

Untuk memvalidasi model secara keseluruhan, maka digunakan goodness of fit (GoF). GoF index ini merupakan ukuran tunggal yang digunakan untuk memvalidasi performa gabungan antara model pengukuran (outer model) dan model structural (inner model).

6) Uji Hipotesis (Resampling Bootstraping)

Berdasarkan tujuan-tujuan penelitian, maka rancangan uji hipotesis yang dapat dibuat merupakan rancangan uji hipotesis dalam penelitian ini disajikan berdasarkan tujuan penelitian. Tingkat kepercayaan yang digunakan adalah $95 \%$, sehingga tingkat presisi atau batas ketidakakuratan sebesar $(\alpha)$ $=5 \%=0,05$. Dimana menghasilkan t-tabel sebesar 1,96. Jika nilai t-statistik lebih besar atau sama dengan t-tabel [t-statistik > 1.96], maka Ho ditolak dan Ha diterima.

\section{HASIL DAN PEMBAHASAN}

1) Analisis Uji Outer Model

Partial Least Square (PLS) merupakan suatu model prediksi yang tidak mengasumsikan distribusi tertentu untuk mengestimasi parameter dan memprediksi hubungan kausalitas, karena itu teknik parametrik bertujuan untuk menguji signifikansi parameter tidak diperlukan dan model evaluasi prediksi tersebut bersifat non-parametrik. Dalam evaluasi model PLS dilakukan dengan analisis outer model dan Inner model, yang dibantu dengan menggunakan software SmartPLS 3.0. Sebelum dilakukan analisis model pengukuran (Outer Model), terlebih dahulu akan disajikan algorithma dalam PLS melalui gambar berikut ini:

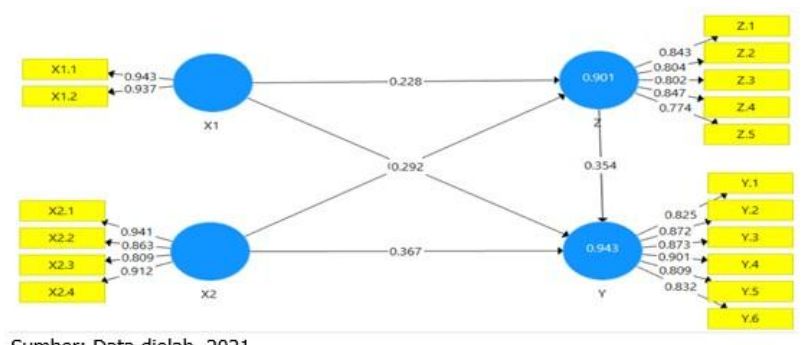

Sumber: Data diolah, 2021

Gambar 1. PLS Algorithma

Berdasarkan gambar PLS Algorithm maka hasil analisis uji validitas dan uji reliabilitas dari setiap 
indikator pada masing-masing variabel penelitian yang dapat diuraikan satu persatu sebagai berikut :

\section{a) Validitas Konvergen}

Validitas Konvergen berhubungan dengan prinsip bahwa pengukur-pengukur dari suatu konstruk seharusnya berkorelasi tinggi. Rule of thumb yang biasanya digunakan untuk menilai validitas konvergen yaitu dengan melihat dari nilai loading factor yang syarat ketentuannya harus lebih dari dari 0,70 untuk penelitian yang bersifat confirmatory dan memiliki nilai loading factor antara 0,60-0,70. Untuk penelitian yang bersifat exploratory masih dapat diterima serta nilai average variance extracted (AVE) harus lebih besar dari 0.50 (Ghozali dan Latan, 2015). Dalam kaitannya dengan uraian tersebut di atas, maka akan disajikan nilai loading factor dari setiap indikator pada masing-masing variabel penelitian yang diolah dengan smartpls 3.0 maka diperoleh hasil untuk kesesuaian pekerjaan individu (person job fit) yang diukur dengan 2 indikator dengan nilai loading factor antara 0,937 - 0,943. Hal ini dapat dikatakan bahwa kedua indikator lebih besar dari 0,70 dan selain itu nilai AVE sebesar 0,883>0,50 berarti kedua indikator memenuhi validitas konvergen yang baik. Kemudian untuk modal manusia dengan nilai loading 0,809-0,941 lebih besar 0,70 dan nilai AVE > 0,50 maka dapat dikatakan bahwa keempat indikator sudah memenuhi validitas konvergen yang baik.

Selanjutnya untuk kepuasan kerja diukur dengan 5 indikator penelitian yang memiliki nilai loading factor 0,802 - 0,847 yang lebih besar dari 0,70 dan nilai AVE $0,663>0,50$, sehingga dapat dikatakan bahwa semua indikator sudah memenuhi validitas konvergen yang baik. Variabel kinerja pegawai dengan 6 indikator yang memiliki nilai loading factor 0,809-0,901 yang lebih besar 0,70 dan nilai AVE 0,727>0,50, hal ini berarti semua indikator sudah memenuhi validitas konvergen. Dari hasil uji validitas konvergen yang telah diuraikan di atas maka dapat disimpulkan bahwa keseluruhan indikator pada masing-masing variabel penelitian sudah memenuhi validitas konvergen yang baik, dengan demikian semua indikator pada setiap variabel penelitian sudah layak untuk digunakan analisis lebih lanjut.

\section{b) Validitas Diskriminan}

Validitas diskriminan berhubungan dengan prinsip bahwa pengukur pengukur konstruk-konstruk yang berbeda seharusnya tidak berkorelasi tinggi. Cara untuk menguji validitas discriminant dengan indikator reflektif yaitu dengan melihat nilai cross loading untuk setiap variabel harus lebih besar dari 0.70 (Ghozali dan Latan, 2015). Berdasarkan hasil nilai cross loading yang menunjukkan bahwa nilai korelasi konstruk dengan indikatornya lebih besar dari pada nilai korelasi dengan konstruk lainnya, dengan demikian bahwa semua konstruk atau variabel laten sudah memiliki discriminant validity yang baik, dimana indikator pada blok konstruk tersebut lebih baik dari pada indikator di blok lainnya.

\section{c) Uji Reliabilitas}

Uji Reliabilitas dilakukan untuk membuktikan akurasi, konsistensi dan ketepatan instrument dalam mengukur konstruk, dalam partial least square (PLS) dengan menggunakan SmartPls 3.0, untuk mengukur reliabilitas suatu konstruk dengan indikator refleksif dapat dilakukan dengan menggunakan dua cara yaitu cronbach's alpha dan composite reliability. Rule of thumb yang biasanya digunakan dalam menguji reliabilitas adalah lebih besar 0,70 (Ghozali dan Latan, 2015). Berdasarkan hasil olahan data dengan menggunakan SmartPLS 3.0 terlihat bahwa nilai cronbach's alpha untuk keempat variabel yang diteliti yakni : person job fit, modal manusia, kepuasan kerja dan kinerja pegawai kontrak yang menunjukkan bahwa nilai cronbach's alpha dan composite reliability lebih besar dari 0,70 berarti dapat disimpulkan semua variabel yang diteliti sudah memiliki reliabilitas yang baik sesuai dengan batas nilai minimum yang diisyaratkan.

\section{2) Analisis Uji Inner Model}

Inner Model merupakan merupakan model structural untuk memprediksi hubungan kausalitas suatu variabel laten, melalui proses bootstrapping, parameter uji Tstatistik diperoleh untuk memprediksi adanya hubungan kausalitas. Nilai koefisien path atau inner model yang ditunjukkan oleh tstatistik harus di atas 1,96 (Abdillah dan Jogiyanto, 2015). Sebelum dilakukan hasil pengujian hipotesis penelitian ini, dapat disajikan gambar bootstrapping dalam SmartPLS 3.0 yaitu :

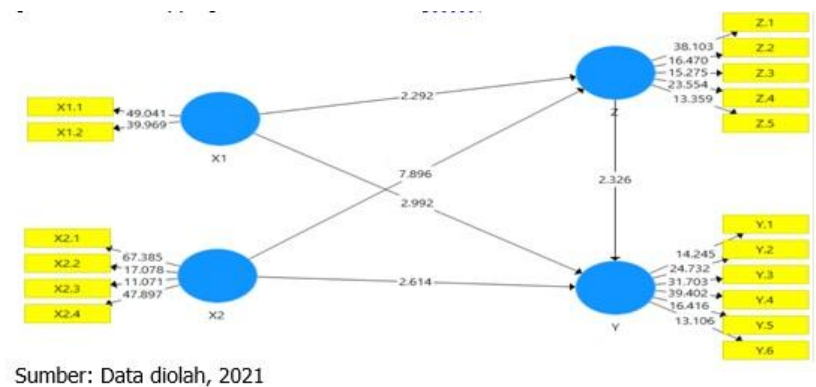

Berdasarkan hasil bootstrapping dalam SmartPls 3.0 yakni analisis path coefficient (Mean, STDEV, TStatistik), maka akan disajikan pengujian hipotesis penelitian adalah :

\section{a) Pengaruh Kesesuaian Pekerjaan Individu Terhadap Kepuasan Kerja}

Hasil analisis path coefficient sebesar 0,228, yang dapat diartikan bahwa setiap kenaikan 1 poin kesesuaian pekerjaan (person job fit) akan meningkatkan kepuasan kerja sebesar 0,228 poin. Hal ini dapat diindikasikan bahwa semakin baik penerapan person job fit, khususnya pada Badan Kepegawaian dan Pengembangan Sumber Daya Manusia Daerah (BKPSDMD), akan dapat meningkatkan kepuasan kerja pegawai kontrak. Kemudian dengan nilai $t$ statistic sebesar 2,292 dan pvalue $=0.022$, sehingga dengan nilai t statistic sebesar $2.292>1.96$ dan $\rho$ value $=0.022>0.05$ maka dapat dikatakan bahwa job person fit berpengaruh secara signifikan terhadap kepuasan kerja pegawai kontrak. Hal 
ini dapat dikatakan bahwa penerapan kesesuaian pekerjaan individu, khususnya Badan Kepegawaian dan Pengembangan Sumber Daya Manusia Daerah (BKPSDMD) dapat memberikan pengaruh secara nyata dalam meningkatkan kepuasan keja.

\section{b) Pengaruh Modal Manusia Terhadap Kepuasan Kerja}

Hasil uji jalur dengan SmartPls 3.0 diperoleh nilai koefisien jalur sebesar 0,752, yang dapat diartikan bahwa setiap kenaikan 1 poin modal manusia akan meningkatkan kepuasan kerja sebesar 0,752. Hal ini dapat diindikasikan bahwa semakin tinggi modal manusia (modal manusia) yang dimiliki oleh Badan Kepegawaian dan Pengembangan Sumber Daya Manusia Daerah (BKPSDMD) maka akan memberikan dampak terhadap kepuasan yang dirasakan oleh pegawai kontrak dalam bekerja. Kemudian dengan nilai tstatistic sebesar 7,896 dan $\rho$ value $=0,000$, dimana dengan tstatistic sebesar $7,896>1,96$ dan dengan nilai $\rho$ value $=0,000<0,05$ maka dapat dikatakan bahwa modal manusia berpengaruh secara signifikan terhadap kepuasan kerja. Dimana dapat disimpulkan bahwa dengan adanya modal manusia maka akan dapat memberikan pengaruh secara nyata dalam meningkatkan kepuasan kerja yang dirasakan oleh pegawai kontrak pada Badan Kepegawaian dan Pengembangan Sumber Daya Manusia Daerah (BKPSDMD).

\section{c) Pengaruh Kesesuaian Pekerjaan Individu Terhadap Kinerja Pegawai Kontrak}

Berdasarkan hasil pengujian jalur dengan menggunakan smartPLS 3,0 yang diperoleh nilai koefisien jalur sebesar 0,292 , hal ini dapat diartikan bahwa setiap kenaikan 1 poin kesesuaian pekerjaan individu, akan meningkatkan kinerja pegawai kontrak Badan Kepegawaian dan Pengembangan Sumber Daya Manusia Daerah (BKPSDMD) sebesar 0,292 poin. Hal ini dapat dikatakan bahwa dengan adanya kesesuaian pekerjaan individu, maka dapat memberikan dampak terhadap peningkatkan kinerja pegawai kontrak. Kemudian dengan tstatistic sebesar 2,992 dan nilai pvalue 0,003 , hal ini menunjukkan bahwa dengan tstatistic $=2,992>1,96$ dan pvalue $=0,003<0,05$, maka dapat dikatakan bahwa kesesuaian pekerjaan individu, berpengaruh signifikan terhadap kinerja pegawai kontrak. Penelitian ini dapat diindikasikan bahwa semakin baik penerapan kesesuaian pekerjaan individu, maka akan memberikan pengaruh secara nyata dalam meningkatkan kinerja pegawai kontrak pada Badan Kepegawaian dan Pengembangan Sumber Daya Manusia Daerah (BKPSDMD). Dengan demikian hipotesis penelitian ini dapat disimpulkan diterima.

\section{d) Pengaruh Modal Manusia Terhadap Kinerja Pegawai Kontrak}

Hasil pengujian jalur dengan menggunakan smartPLS 3.0 maka diperoleh nilai kofisien jalur sebesar 0,367 . Nilai koefisien jalur dapat diinterpretasikan bahwa setiap kenaikan 1 poin sebesar 1 poin modal manusia maka akan meningkatkan kinerja pegawai kontrak pada
Badan Kepegawaian dan Pengembangan Sumber Daya Manusia Daerah (BKPSDMD) sebesar 0,367. Sehingga dapat diindikasikan bahwa semakin tinggi modal manusia (human capital) maka akan dapat memberikan dampak dalam meningkatkan kinerja pegawai kontrak. Kemudian dilihat dari nilai tstatistic sebesar 2,614 dan pvalue $=$ 0,009 , sehingga dengan nilai tstatistic sebesar 2,614 > 1,96 dan dengan nilai $\rho$ value $=0,009>0.05$ maka dapat dikatakan bahwa modal manusia berpengaruh secara signifikan terhadap kinerja pegawai kontrak. Hal ini dapat disimpulkan bahwa modal manusia memberikan pengaruh secara nyata dalam meningkatkan kinerja pegawai kontrak pada BKPSDMD kota Makassar.

\section{e) Pengaruh Kepuasan Kerja Terhadap Kinerja Pegawai Kontrak}

Hasil pengujian jalur maka diperoleh nilai koefisien sebesar 0,354, dimana dapat dikatakan bahwa setiap kenaikan 1 poin kepuasan kerja maka akan diikuti oleh adanya kinerja pegawai kontrak pada Badan Kepegawaian dan Pengembangan Sumber Daya Manusia Daerah (BKPSDMD) kota Makassar yakni sebesar 0,354 poin. Dimana dapat diindikasikan bahwa semakin tinggi kepuasan yang dirasakan oleh pegawai dalam bekerja maka akan diikuti oleh adanya peningkatan kinerja pegawai kontrak. Kemudian dengan nilai statistic sebesar 2,326 dan $\rho$ value $=0,022$, dengan nilai statistic sebesar $2,326>1,96$ dan nilai $\rho$ value sebesar $0,022<0,05$. Dimana dapat disimpulkan bahwa kepuasan kerja berpengaruh secara signifikan terhadap kinerja pegawai kontrak, hal ini dapat diindikasikan bahwa kepuasan kerja memberikan pengaruh secara nyata dalam meningkatkan kinerja pegawai kontrak pada Badan Kepegawaian dan Pengembangan Sumber Daya Manusia Daerah (BKPSDMD).

Selanjutnya akan dilakukan hasil pengujian pengaruh tidak langsung yang dapat dilihat pada gambar berikut ini :

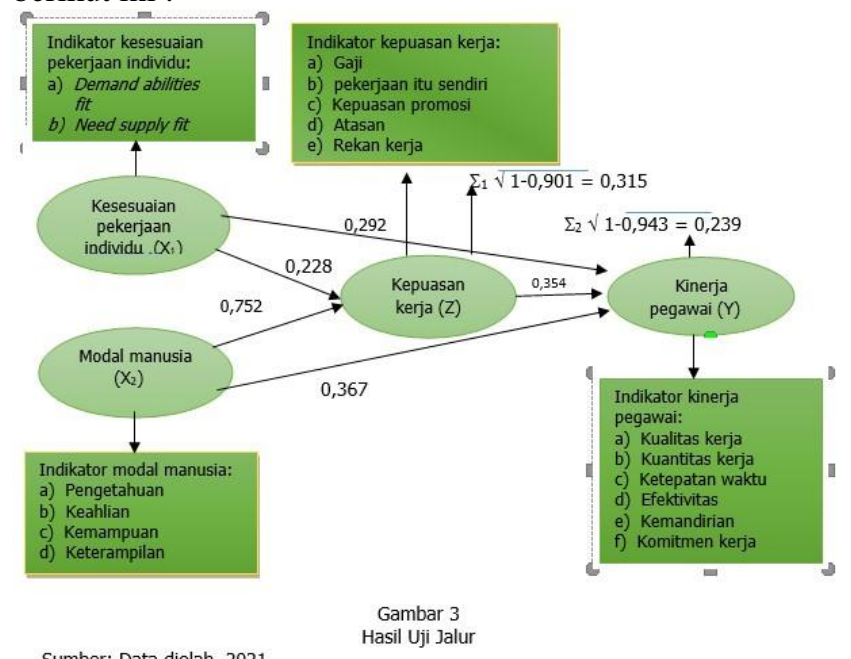

f) Pengaruh Kesesuaian Pekerjaan Individu Terhadap Kinerja Pegawai Kontrak Melalui Kepuasan Kerja

Berdasarkan koefisien jalur kesesuaian pekerjaan individu terhadap kinerja 
pegawai kontrak Melalui Kepuasan kerja maka akan dilakukan perhitungan pengaruh langsung, tidak langsung dan total pengaruh yaitu :

Besarnya pengaruh langsung

Besarnya pengaruh tidak langsung :

Kesesuaian pekerjaan individu terhadap kinerja

Pegawai kontrak melalui kepuasan kerja

$(0,228 \times 0,354)$

$\underline{0,080}$

(+)

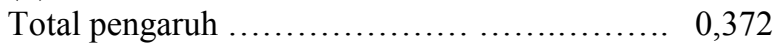

Dari hasil perhitungan tersebut di atas maka besarnya pengaruh langsung kesesuaian pekerjaan individu, terhadap kinerja pegawai kontrak sebesar 0,292 atau 29,20\%, sedangkan besarnya pengaruh tidak langsung kesesuaian pekerjaan individu, terhadap kinerja pegawai kontrak melalui kepuasan kerja sebesar 0,080 atau $8 \%$. Dengan demikian maka besarnya total pengaruh kesesuaian pekerjaan individu terhadap kinerja pegawai kontrak melalui kepuasan kerja pada Badan Kepegawaian dan Pengembangan Sumber Daya Manusia Daerah (BKPSDMD) sebesar 0,372 atau 37,20\%.

Kemudian akan dilakukan pembuktian bahwa kepuasan kerja dapat memediasi pengaruh kesesuaian pekerjaan individu terhadap kinerja pegawai kontrak maka dapat digunakan uji sobel test, adapun hasil uji sobel test statistic secara online melalui tabel berikut ini :

Tabel 1. Hasil Uji Sobel Test Statistic Pengaruh kesesuaian pekerjaan individu terhadap kinerja pegawai kontrak melalui kepuasan kerja
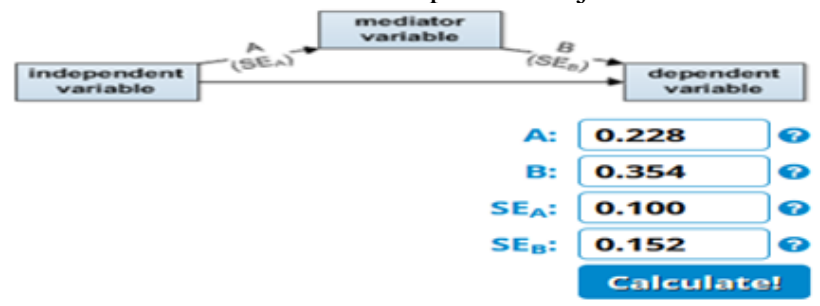

Sobel test statistic: 1.62923331 One-tailed probability: 0.05163182 Two-tailed probability: 0.10326364

Data hasil uji mediasi pengaruh kesesuaian pekerjaan individu terhadap kinerja pegawai kontrak melalui kepuasan kerja pada Badan Kepegawaian dan Pengembangan Sumber Daya Manusia Daerah yang menunjukkan bahwa nilai sobel test statistic sebesar 1,629 dan memiliki pvalue sebesar 0,103, karena dengan nilai sobel test statistic sebesar 1,629 < 1,96 dan $\rho$ value $=$ $0,103>0,05$, maka dapat dikatakan bahwa kepuasan kerja tidak dapat memediasi pengaruh person job fit terhadap kinerja pegawai kontrak. Hal ini disebabkan, karena masih adanya beberapa pegawai yang memberikan tanggapan bahwa dalam penerapan kesesuaian pekerjaan individu (person job fit), yakni yang berhubungan kemampuan pegawai kontrak yang diperoleh dari pendidikan dan pengalaman dianggap masih kurang sesuai dengan tuntutan pekerjaan pegawai kontrak saat ini. g) Pengaruh Modal Manusia Terhadap Kinerja Pegawai Kontrak Melalui Kepuasan Kerja

Dari hasil pengujian pengaruh tidak langsung modal manusia terhadap kinerja pegawai kontrak maka dapat dilakukan perhitungan pengaruh tidak langsung yaitu sebagai berikut :

Besarnya pengaruh langsung. 0.367

Besarnya pengaruh tidak langsung :

Modal manusia terhadap kinerja pegawai kontrak

Melalui kepuasan kerja $(0,752 \times 0,354) \ldots \ldots \ldots \underline{0,266(+)}$

Total pengaruh $\ldots \ldots \ldots \ldots \ldots \ldots \ldots \ldots \ldots \ldots \ldots . . .633$

Berdasarkan hasil perhitungan besarnya pengaruh langsung yaitu sebesar 0,367 atau 36,70\%, sedangkan besarnya pengaruh tidak langsung modal manusia terhadap kinerja pegawai kontrak melalui kepuasan kerja sebesar 0,266 atau 26,60\%. Dengan demikian maka besarnya total pengaruh modal manusia terhadap kinerja pegawai kontrak melalui kepuasan kerja sebesar 0,633 atau 63,30\%. Kemudian pembuktian bahwa kepuasan kerja dapat memediasi pengaruh modal manusia terhadap kinerja pegawai kontrak maka dapat digunakan uji sobel test statistic yang dapat dilihat melalui tabel yaitu sebagai berikut :

Tabel 2. Hasil uji Sobel Test statistic Pengaruh Modal manusia terhadap kinerja pegawai kontrak melalui kepuasan kerja

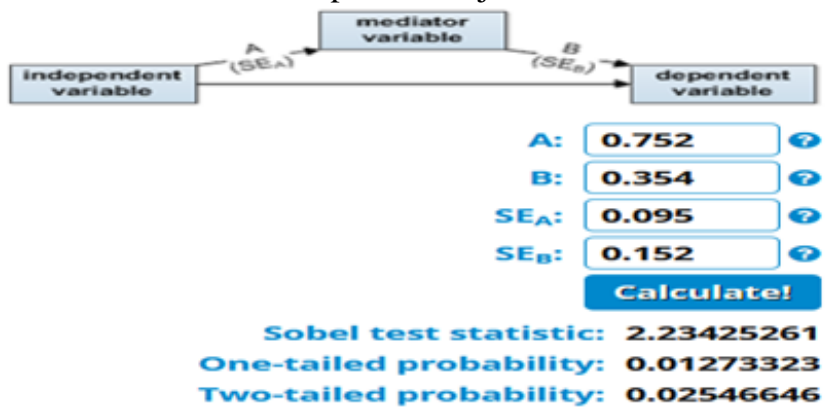

Hasil uji sobel test, diperoleh nilai sobel test sebesar 2,234 dan nilai $\rho$ value sebesar 0,025 . Dengan nilai sobel test 2,234>1,96 dan selain itu nilai $\rho$ value sebesar 0,025 < 0,05, maka dapat dikatakan bahwa kepuasan kerja dapat memediasi pengaruh antara modal manusia terhadap kinerja pegawai kontrak. Hal ini dapat diindikasikan bahwa dengan adanya modal manusia akan meningkatkan kepuasan kerja sehingga memberikan dampak terhadap kinerja pegawai kontrak pada Badan Kepegawaian dan Pengembangan Sumber Daya Manusia Daerah BKPSDMD.

\section{3) Pengaruh Kesesuaian Pekerjaan Individu, Terhadap Kepuasan Kerja}

Hasil analisis mengenai pengaruh kesesuaian pekerjaan individu terhadap kepuasan kerja menunjukkan bahwa person job fit yang diterapkan oleh Badan Kepegawaian dan Pengembangan Sumber Daya Manusia Daerah di kota Makassar sudah berada dalam kategori baik ditinjau dari demand abilities fit dan need supply fit, walaupun masih ada pegawai kontrak yang memberikan 
tanggapan belum sesuai dengan tuntutan pekerjaan saya saat ini. Hal ini dapat dilihat bahwa dari 4 item pernyataan yang berkaitan dengan kesesuaian pekerjaan individu, ternyata skor jawaban responden yang terkecil adalah saya merasa kemampuan yang saya peroleh dari pendidikan dan pengalaman sesuai dengan tuntutan pekerjaan saya saat ini, hal ini dikarenakan pendidikan dan pengalaman yang selama ini dimiliki oleh pegawai kontrak tidak sesuai dengan tuntutan pekerjaan. Kemudian skor jawaban yang tertinggi adalah adanya kesesuaian antara kebutuhan organisasi dengan kemampuan yang telah saya miliki. Dimana dari hasil penyebaran kuesioner kepada pegawai kontrak telah mempersepsikan bahwa sudah ada kesesuaian antara kebutuhan organisasi dengan kemampuan yang pegawai kontrak miliki.

Berdasarkan hasil analisis data yang dilakukan maka diperoleh temuan bahwa kesesuaian pekerjaan individu, berpengaruh positif dan signifikan terhadap kepuasan kerja pada Badan Kepegawaian dan Pengembangan Sumber Daya Manusia Daerah di kota Makassar. Hal ini dapat dikatakan bahwa dengan adanya kesesuaian pekerjaan dengan tuntutan organisasi maka hal ini memberikan kepuasan kerja bagi setiap pegawai kontrak dalam bekerja. Hal ini sesuai dengan pendapat Peng dan Mao (2014) menyatakan bahwa kesesuaian pekerjaan individu (person job-fit) dikatakan dapat meningkatkan efikasi diri yang kemudian dapat memberikan kepuasan kerja ketika pegawai berhasil mencapai performa yang lebih baik dalam pekerjaannya.

Temuan yang diperoleh peneliti sejalan dengan hasil penelitian yang dilakukan oleh Penelitian Widyastuti, Titis dan Ratnaningsih (2018) hasil penelitian menunjukkan adanya hubungan positif yang signifikan antara kesesuaian pekerjaan individu (person job-fit) dengan kepuasan kerja.

\section{4) Pengaruh Modal Manusia Terhadap Kepuasan Kerja}

Berdasarkan hasil penyebaran kuesioner yang diberikan kepada pegawai kontrak maka diperoleh hasil analisis bahwa modal manusia yang dimiliki oleh pegawai kontrak sudah dipersepsikan baik dilihat dari segi pengetahuan, keahlian, kemampuan dan keterampilan. Namun masih ada sebagian pegawai kontrak yang mempersepsikan dilihat dari keterampilan bahwa setiap pegawai kontrak yang ditempatkan belum sesuai dengan bidang skill yang dimiliki. Sedangkan skor tertinggi pada indikator kemampuan dimana setiap pegawai kontrak memiliki kemampuan dalam bekerja, ini dapat dilihat bahwa setiap pegawai kontrak dapat menyelesaikan setiap pekerjaan yang diberikan. Kemudian pengetahuan pegawai mendukung dalam penyelesaian pekerjaan menurut tupoksi, hal ini dapat dilihat bahwa organisasi sering melakukan diklat-diklat, sehingga dengan adanya diklat tersebut dapat memberikan pengetahuan bagi setiap pegawai kontrak. Dari hasil analisis yang dilakukan maka dapat dikatakan bahwa modal manusia berpengaruh positif dan signifikan terhadap kepusan kerja. Hal ini sesuai dengan teori yang dikemukakan oleh Affandi (2016) bahwa hasil analisis yang diperoleh memberikan indikasi bahwa semakin baik modal manusia maka semakin baik pula kepuasan kerja yang dirasakan.

Temuan penelitian ini sejalan dengan penelitian yang dilakukan oleh Ismykabhani Nuraji dan Muhammad Zakiy (2018), hasil penelitian menemukan bahwa modal manusia berpengaruh signifikan terhadap kepuasan kerja. Dimana semakin tinggi modal manusia melalui pengetahuan, keterampilan, dan keahlian yang dimiliki oleh pegawai maka akan memberikan kepuasan kerja bagi pegawai.

\section{5) Pengaruh Kesesuaian Pekerjaan Individu Terhadap Kinerja Pegawai Kontrak}

Berdasarkan hasil analisis yang dilakukan maka dapat diketahui bahwa kesesuaian pekerjaan individu berpengaruh positif dan signifikan terhadap kinerja pegawai kontrak. Dimana dari hasil atau kesesuaian pekerjaan individu melalui penyebaran kuesioner mengenai kesesuaian pekerjaan individu, menunjukkan bahwa Badan Kepegawaian dan Pengembangan Sumber Daya Manusia Daerah di kota Makassar sudah melakukan kesesuaian pekerjaan bagi setiap pegawai kontrak yang disesuaikan dengan kemampuan yang pegawai kontrak miliki. Begitu pula bahwa setiap pegawai kontrak merasa sudah terdapat kesesuaian pekerjaan dengan yang ditawarkan oleh organisasi saat ini sehingga hal ini dapat memberikan peningkatan kinerja pegawai kontrak. Hal ini sesuai dengan teori yang dikemukakan oleh Bowen, et.al. (1997) bahwa kesesuaian pekerjaan individu (person job fit) memperhitungkan jenis-jenis individu yang diperlukan dengan kualifikasi: kesesuaian knowledge (pengetahuan), skill (keterampilan), abilities (kemampuan), social skills (keterampilan sosial), personal needs (kebutuhan individu), values (nilai-nilai), interest (minat) dan personality traits (sikap individu). Dengan demikian penting bagi organisasi untuk melakukan penyesuaian pekerjaan individu, sehingga memperoleh kinerja individu yang optimal. Hasil penelitian ini sejalan dengan penelitian yang telah dilakukan oleh Jeanita (2017), Alfani, Muhammad dan M. Hadini (2018), serta Izmam Wahjudhy, dkk. (2014) dimana dari penelitian bahwa person job fit memiliki pengaruh positif dan signifikan terhadap Kinerja Karyawan.

\section{6) Pengaruh Modal Manusia Terhadap Kinerja Pegawai Kontrak}

Hasil penyebaran kuesioner yang telah dikemukakan yakni berkaitan dengan modal manusia dimana modal manusia yang dimiliki oleh setiap sudah termasuk dalam kategori baik. Hal ini dapat dilihat dari skor jawaban responden yang tetinggi untuk pengetahuan bahwa pengetahuan pegawai kontrak mendukung dalam penyelesaian pekerjaan menurut tupoksi, kemudian ditinjau dari keahlian maka setiap pegawai kontrak memiliki keahlian dalam bekerja. Sedangkan ditinjau dari kemampuan (ability) bahwa setiap pegawai kontrak memiliki kemampuan dalam bekerja. Dilihat dari keterampilan maka ketrampilan kerja sangat menentukan 
posisi pegawai kontrak di tempat kerja. Semakin baik modal manusia maka semakin tinggi kinerja pegawai kontrak. Hal ini sesuai dengan teori yang dikemukakan oleh Gaol (2014:696) bahwa Modal manusia adalah pengetahuan (knowledge), keahlian (expertise), kemampuan (ability) dan keterampilan (skill) yang menjadikan manusia atau karyawan sebagai modal atau asset suatu perusahaan. Dimana Maksudnya adalah apabila di dalam suatu perusahaan seorang karyawan dijadikan sebagai modal keuntungan maka perusahaan tersebut akan mendapatkan keuntungan yang lebih besar dari pada sebuah perusahaan hanya menganggap seorang karyawan sebagai sumber daya atau human resource. Dengan mengandalkan dengan keahlian, kemampuan dan keterampilan maka seorang karyawan dapat menjalankan sumber daya yang lainnya. Temuan penelitian ini sejalan dengan penelitian yang dilakukan oleh Prayedi Cahya Nugraha, Heru Susilo, Edlyn Khurotul Aini (2018), dimana hasil temuan bahwa modal manusia berpengaruh positif dan signifikan terhadap kinerja perusahaan.

\section{7) Pengaruh Kepuasan Kerja Terhadap Kinerja Pegawai Pegawai}

Berdasarkan hasil penyebaran kuesioner terkait dengan kepuasan kerja, maka rata-rata pegawai kontrak memberikan persepsi bahwa kepuasan kerja sudah berada dalam kategori tinggi. Hal ini dapat dilihat bahwa puas dengan gaji yang diterima karena sesuai tanggungjawab dalam bekerja, dimana dapat dilihat bahwa setiap pegawai kontrak mendapatkan gaji yang memadai. Kemudian pembagian kelompok kerja sesuai dengan ketrampilan yang dimiliki, dimana setiap pegawai kontrak dibentuk tim-tim kerja sehingga memberikan kemudahan bagi pegawai kontrak dalam bekerja. Indikator bahwa adanya kebijakan promosi jabatan yang dilaksanakan selama ini, hal ini dapat dilihat bahwa setiap pegawai kontrak akan mendapatkan promosi jabatan dari pimpinan, sehingga memudahkan untuk diangkat menjadi PNS. Kemudian setiap pegawai kontrak puas dengan kemampuan atasan dalam mengarahkan setiap pegawai kontrak dalam bekerja, hal ini dapat dilihat bahwa pimpinan selalu melakukan monitoring atau memantau hasil kerja pegawai kontrak, begitu pula bahwa setiap pegawai kontrak merasa puas dengan adanya kerjasama dengan sesama rekan kerjanya dalam bekerja.

Hasil analisis yang dilakukan menunjukkan bahwa kepuasan kerja berpengaruh positif dan signifikan terhadap kinerja pegawai kontrak, sebagaimana dikemukakan oleh Malthis dan Jackson (2015) bahwa kepuasan kerja itu menarik dan penting, hal yang paling mendasar adalah pengaruh kepuasan kerja terhadap organisasi yang akan mempengaruhi kinerja karyawan. Dengan demikian dapat disimpulkan bahwa pengaruh kepuasan kerja terhadap kinerja adalah tinggi rendahnya tingkat kepuasan kerja karyawan yang dirasakan akan mempengaruhi kinerja karyawan. Apabila kepuasan kerja tercapai maka kinerja karyawan atas organisasi tinggi. Temuan penelitian ini sejalan dengan penelitian yang dilakukan oleh Jeanita
Hinayah Arifianingsih (2017), begitu pula dengan penelitian Ayuningtyas, and I. Djastuti menemukan bahwa kepuasan kerja berpengaruh positif dan signifikan terhadap kinerja karyawan, dimana semakin tinggi perasaan puas karyawan maka semakin tinggi pula kinerja yang dicapai.

\section{8) Pengaruh Kesesuaian Pekerjaan Individu Terhadap Kinerja Pegawai Kontrak Melalui Kepuasan Kerja}

Berdasarkan hasil penelitian yang dilakukan maka dapat dikatakan bahwa kepuasan kerja tidak dapat memediasi pengaruh person job fit terhadap kinerja pegawai kontrak. Hal ini disebabkan, karena masih adanya beberapa pegawai kontrak yang memberikan tanggapan bahwa dalam penerapan kesesuaian pekerjaan individu (person job fit), yakni yang berhubungan kemampuan pegawai kontrak yang diperoleh dari pendidikan dan pengalaman dianggap masih kurang sesuai dengan tuntutan pekerjaan pegawai kontrak saat ini. Hasil temuan ini sejalan dengan penelitian yang dilakukan oleh Fidyannissa, Author (2013) menemukan bahwa kepuasan kerja tidak dapat menjadi variabel mediator pada pengaruh person job fit terhadap kinerja pegawai di Kelompok Wilayah I Direktorat Jenderal Pajak.

9) Pengaruh Modal Manusia Terhadap Kinerja Pegawai Kontrak Melalui Kepuasan Kerja

Dari hasil uji sobel test mengenai pengaruh tidak langsung antara modal manusia terhadap kinerja pegawai kontrak melalui kepuasan kerja, hal ini dapat dikatakan bahwa kepuasan kerja dapat memediasi pengaruh antara modal manusia terhadap kinerja pegawai kontrak. Hal ini dapat diindikasikan bahwa dengan adanya modal manusia akan meningkatkan kepuasan kerja sehingga memberikan dampak terhadap kinerja pegawai kontrak pada Badan Kepegawaian dan Pengembangan Sumber Daya Manusia Daerah. Hal ini sejalan dengan temuan penelitian yang dilakukan oleh Jeanita Hinayah Arifianingsih (2017) menunjukkan bahwa kepuasan kerja berpengaruh signifikan terhadap kinerja karyawan. Begitu pula dengan penelitian Paradiptha (2013) menemukan adanya hubungan yang kuat antara modal manusia dan kepuasan kerja terhadap kinerja pegawai, bahwa pegawai dengan kemampuan/skill dalam pekerjaan dengan tingkat kepuasan kerja yang tinggi akan mempunyai kinerja yang tinggi pula terhadap organisasi.

\section{KESIMPULAN DAN SARAN}

Hasil penelitian dapat disimpulkan bahwa kesesuaian pekerjaan individu, berpengaruh terhadap kepuasan kerja, hal ini menunjukkan semakin baik penerapan kesesuaian pekerjaan individu maka akan memberikan dampak secara nyata terhadap peningkatan kepuasan kerja. Pengaruh person job fit memberikan pengaruh secara nyata terhadap peningkatan kinerja pegawai kontrak. Pengaruh kepuasan kerja terhadap kinerja pegawai kontrak, temuan penelitian ini 
memberikan indikasi bahwa semakin tinggi kepuasan kerja pegawai maka akan memberikan pengaruh secara nyata terhadap peningkatan kinerja pegawai kontrak.

\section{DAFTAR PUSTAKA}

A. Ayuningtyas, and I. Djastuti, (2017) "Analisis Pengaruh Pemberdayaan dan Pengembangan Karir Terhadap Kinerja Karyawan Dengan Kepuasan Kerja Sebagai Variabel Intervening (Studi pada Karyawan PDAM Tirta Moedal Kota Semarang), Diponegoro Journal of Management, vol. 6, No. 3, pp. 9-13, Aug. 2017. [Online]. plugins. citation Formats. ieee.retrieved.

Abdillah, Willy dan Jogiyanto Hartono. 2016. Partial Least Square (PLS): Alternatif Structural Equation Modeling (SEM) dalam Penelitian Bisnis. Penerbit : Andi, Yogyakarta

Alfani, Muhammad dan M. Hadini (2018), Pengaruh Person Job Fit dan Person Organization Fit terhadap OCB dan Kinerja Karyawan Universitas Islam Kalimantan Muhammd Arsyad Al Banjari Kalimantan, Jurnal Riset Inspirasi Manajemen Dan Kewirausahaan Volume 2 No. 2 Edisi September 2018, ISSN: 2549-3477 e-ISSN: 2623-1077

Affandi, Pandi. 2018. Manajemen Sumber Daya Manusia : Teori, Konsep dan Indikator. Cetakan Pertama, Penerbit : Zanafa Publishing, Pekanbaru.

Bowen, DE., Ledford, GE and Nathan,BR., (1997), Hiring for The Organization, Not The Job, Academy of Management Executive, Vol. 5., No. 5.

Fidyannissa, (2013) Pengaruh Person Job Fit Terhadap Kinerja Pegawai Dengan Kepuasan Kerja Sebagai Variabel Mediator : Studi Kasus Pada Kelompok Wilayah I Direktorat Jenderal Pajak. Tesis Universitas Indonesia

Gaol L, Jimmy (2014). A to Z Modal manusia : Manajemen Sumber Daya Manusia. Penerbit : Grasindo : Jakarta

Ghozali Imam, 2018, Aplikasi Analisis Multivariate Dengan Program IBM SPSS 25, edisi kesembilan, cetakan kesembilan, Badan Penerbit : Universitas Diponegoro Semarang

Ismykabhani Nuraji dan Muhammad Zakiy (2018) Pengaruh Person Job fit dan Person Organizational Fit Terhadap Organization Citizenship Behaviour (OCB) Melalui Kepuasan Kerja Sebagai Variabel Mediasi. Jurnal Universitas Muhammadiyah Yogyakarta

Izmam Wahjudhy, dkk (2014) Analisis Pengaruh Person Job Fit dan Kepuasan Kerja Terhadap Kinerja Karyawan Pada CV. Pion Pring Jurnal Binus University, Jakarta, Indonesia.

Jeanita Hinayah Arifianingsih (2017) Pengaruh Person Organization Fit Terhadap Kinerja Karyawan Melalui Kepuasan Kerja Sebagai Variabel Intervening (Studi Kasus Pada Karyawan Lottemart
Wholesale) Jurnal Universitas Islam Negeri Syarif Hidayatullah Jakarta.

Malthis dan Jackson, 2015, Manajemen Sumber Daya Manusia, Edisi kelima, Yogyakarta

Mayo, A. 2000. "The Role of Employee Development in The Growth of Intellectual Capital" dalam Personal Review, Vol. 29, No. 4.

Peng, Y., \& Mao, C. (2014). The Impact of Person Job Fit on Job Satisfaction: The Mediator Role of Self Efficacy. School of Business Hunan University. DOI: 10.1007/s11205-014-0659-x

Prayedi Cahya Nugraha, Heru Susilo, Edlyn Khurotul Aini, (2018) Pengaruh Modal manusia Terhadap Kinerja Perusahaan (Studi pada Perusahaan Advertising dan Periklanan Malang Yang Terdaftar pada Asosiasi Advertising dan Periklanan Malang). Jurnal Administrasi Bisnis (JAB)| Vol. 57 No. 2 April 2018| Administrasi Bisnis. Student Journal.ub.ac.id.

Priansa, Donni Juni. 2018. Perencanaan \& Pengembangan SDM. Bandung. Alfabeta.

Sugiyono. 2017. Metode Penelitian Kuantitatif, Kualitatif, dan R\&D. Penerbit : Alfabeta, Bandung

Titis Widyastuti, Ika Zenita Ratnaningsih, (2018) Hubungan Antara Person Job Fit Dengan Kepuasan Kerja pada Karyawan Kantor Pusat Bank Jateng Semarang. Jurnal Empati, Agustus 2018, Volume 7 (Nomor 3), Halaman 73-79.

Widodo, 2015. Manajemen Pengembangan Sumber Daya Manusia, Penerbit : Pusaka Pelajar. Yogyakarta. 